\section{Journal of Energy \&. \\ Environmental Sciences}

Vol. 4, $\mathrm{N}^{\circ} 1,2020$

\title{
Removal of Copper and Cadmium in Wastewater Applying Activated Carbon: A Review of Articles [Remoción de cobre y cadmio en aguas residuales mediante la aplicación de carbón activado: revisión de artículos]
}

Jhonny Valverde Flores

Universidad Nacional Agraria La Molina, Lima, Peru. jvalverde@lamolina.edu.pe

Received: 20 May 2020; Accepted: 22 August 2020; Published: 26 October 2020

\section{Resumen}

La investigación tuvo como objetivo revisar la bibliografía de artículos referentes a la remoción de Cobre y Cadmio en aguas residuales aplicando carbón activado. Los resultados indican que la almendra logra mejores resultados para remoción de cobre y el melón de roca logra mejores resultados para remoción de cadmio.

Palabras clave: Carbon activado, aguas residuales, cobre, cadmio.

\begin{abstract}
The objective of the investigation was to review the bibliography of articles referring to the elimination of Copper and Cadmium in wastewater by applying activated carbon. The results indicate that the almond achieves better results for the removal of Copper and the rock melon achieve better results for the removal of Cadmium.
\end{abstract}

Keywords: Activated carbon, wastewater, Copper, Cadmium.

\section{Introduction}

At least 20 metals are classified as toxic and half of these are emitted into the environment in quantities that pose risks to human health (Nomanbhay and Palanisamy, 2005). The important toxic metals i.e. lead $(\mathrm{Pb})$, cadmium $(\mathrm{Cd})$, zinc $(\mathrm{Zn})$, and copper $(\mathrm{Cu})$ find its way to the water bodies through wastewaters (Mahvi et al., 2005).

Adsorption using commercial activated carbon (CAC) is an effective purification and separation technique used in industry especially in water and wastewater treatments that can remove heavy metals from wastewater (Gun et al, 2005). Activated carbon surfaces have a pore size that determine its adsorption capacity, a chemical structure that influences its interaction with polar and non-polar adsorbates, and active sites which determine the type of chemical reactions with other molecules (Ahmedna et al., 2004) 


\section{Journal of Energy \&. Environmental Sciences}

Vol. 4, $\mathrm{N}^{\circ} 1,2020$

Copyright @ 2020 , CINCADER.

ISSN 2523-0905

DOI: https://doi.org/10.32829/eesj.v4i1.196

\section{Materials and Methods}

To carry out the research, the systematic review methodology was chosen and its purpose is to compile and provide a summary on a certain topic and once the research question has been answered. Consequently, this research applies a systematic review to analyze and estimate the information obtained from various studies with multiple results, to evaluate the application of activated carbon in the removal of Copper and Cadmium in wastewater.

The adsorption of metals by activated carbon is shown in the following figure.
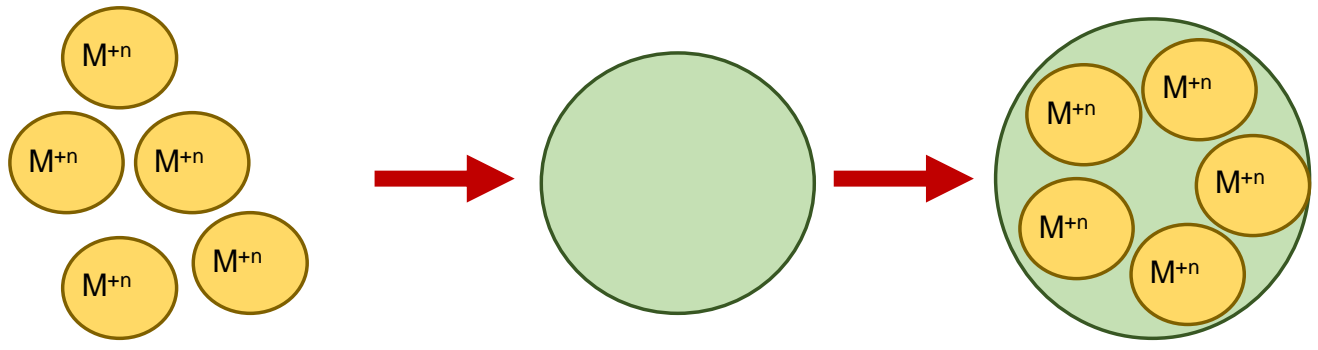

Figure 1. adsorption of metals by activated carbon

\section{Results}

The following investigations have been found: using almond husk as activated carbon reduced $94.7 \%$ of $\mathrm{Cu}$ and $93.7 \%$ of $\mathrm{Cd}$ (Hasar and Cuci, 2000), rock melon as activated carbon reduced $95.6 \%$ of $\mathrm{Cu}$ and $98.5 \%$ of $\mathrm{Cd}$ (Nurdin et al., 2006), granular activated carbon reduced $89 \%$ of $\mathrm{Cu}$ and $60.1 \%$ of $\mathrm{Cd}$ (Üçer et al., 2000), apricot stone as carbon activated reduced $95.5 \%$ of $\mathrm{Cu}$ and $86 \%$ of $\mathrm{Cd}$ (Kazemipour et al., 2008), walnut as activated carbon reduced $97.5 \%$ of $\mathrm{Cu}$ and $50.9 \%$ of $\mathrm{Cd}$ (Kazemipour et al., 2008), hazelnut as activated carbon reduced $92.9 \%$ of $\mathrm{Cu}$ and $90.5 \%$ of $\mathrm{Cd}$ (Kazemipour et al., 2008), almond as activated carbon reduced $99.8 \%$ of $\mathrm{Cu}$ and $74.8 \%$ of $\mathrm{Cd}$ (Kazemipour et al., 2008), pistachio as activated carbon reduced $83 \%$ of $\mathrm{Cu}$ and $33.8 \% \mathrm{Cd}$ (Kazemipour et al., 2008). 


\section{Journal of Energy \&. Environmental Sciences}

Vol. 4, $\mathrm{N}^{\circ}$ 1, 2020

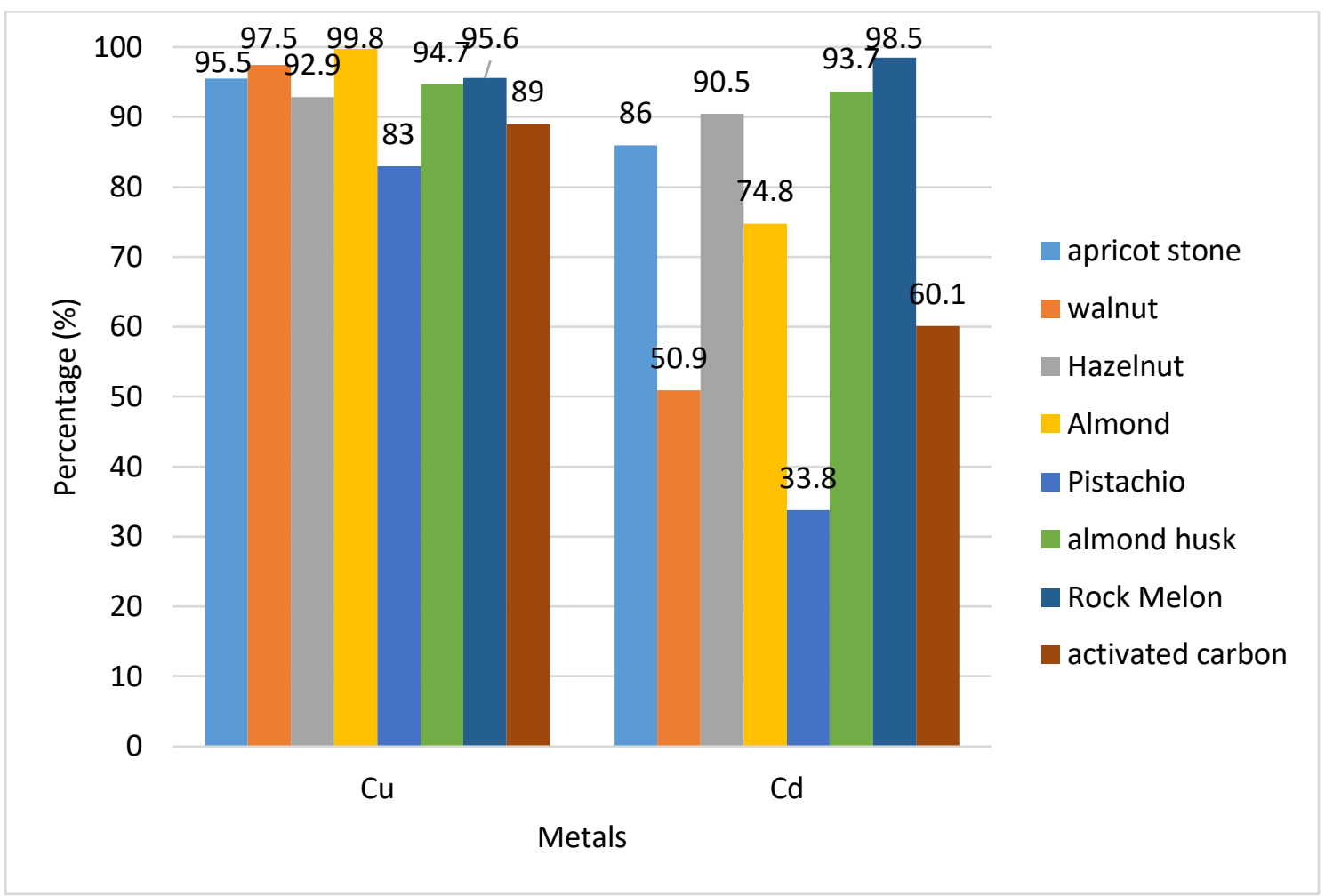

Figure 2. Comparison of activated carbon to remove $\mathrm{Cu}$ and $\mathrm{Cd}$

\section{Conclusions}

According to the results obtained by authors, it can be concluded that:

- The results indicate that the almond achieves better results for the removal of Copper and the rock melon achieve better results for the removal of Cadmium.

\section{References}

Ahmedna M., Marshall W.E., Husseiny A.A., Rao R.M., Goktepe I., 2005, The use of nutshell carbons in drinking water filters for removal of trace metals, Water Res. 38 (2004) 10621068.

Gun V.M., Leboda R., Skubiszewska-Zie ba J., Charmas B., Oleszczuk P., Carbon adsorbents from waste ion-exchange resins, Carbon 43 1143-1150.

Hasar H., Cuci Y., 2000, Removal of $\mathrm{Cr}(\mathrm{VI}), \mathrm{Cd}(\mathrm{II})$, and $\mathrm{Cu}(\mathrm{II})$ by activated carbon prepared from almond husk. Environmental technology, vol 21, pp 1337-1342. DOI: 10.1080/09593332208618172

Kazemipour Maryam, Ansari M., Reihani Kermani H., 2007, Removal of lead, cadmium, zinc, and copper from industrial wastewater by carbon developed from walnut, hazelnut, almond, pistachio shell, and apricot stone. Journal of Hazardous Materials. 31 January 2008, https://doi.org/10.1016/j.jhazmat.2007.04.118 


\section{Journal of Energy \&. Environmental Sciences}

Vol. 4, $\mathrm{N}^{\circ} 1,2020$

Copyright (C) 2020, CINCADER.

ISSN 2523-0905

DOI: https://doi.org/10.32829/eesj.v4i1.196

Mahvi A.H., Naghipour D., Vaezi F., Nazmara S., 2005, Teawaste as an adsorbent for heavy metal removal from industrial wastewaters, Am. J. Appl. Sci. 2 372-375.

Nomanbhay S.M., Palanisamy K., 2005, Removal of heavy metal from industrial wastewater using chitosan coated oil palm shell charcoal, Electron. J. Biotech. 8 43-53.

Nurdin S, Roslan A., Abbakar MS, Khairuddin S, Sukri HA. 2015, Rock Melon Activated Carbon (RMAC) for Removal of $\mathrm{Cd}(\mathrm{II}), \mathrm{Ni}(\mathrm{II})$ and $\mathrm{Cu}(\mathrm{II})$ from Wastewater: Kinetics and Adsorption Equilibrium, International Journal of Chemical Engineering and Applications, Vol. 6, No. 2, DOI: 10.7763/IJCEA.2015.V6.461

Üçer A, Uyanik A, Aygün SF, 2006, Adsorption of $\mathrm{Cu}(\mathrm{II}), \mathrm{Cd}(\mathrm{II}), \mathrm{Zn}(\mathrm{II}), \mathrm{Mn}(\mathrm{II})$ and Fe(III) ions by tannic acid immobilised activated carbon. Separation and Purification Technology, Volume 47, Issue 3, Pages 113-118. 